\title{
スライム及びパルプに発生する微生物についで
}

\author{
五十嵐 長 司** \\ 赤堀 五 郎***
}

\section{SLIME AND MICRO-ORGANISMS IN PULP AND PAPER MIILS}

By Choji Igarashi and Goro Akabori

Being isolated from slimes gathered in various places of pulp and paper mill machine processes, various micro-organisms were classified by kinds, and methods to prevent their growth were seriously studied. Furthermore, various experiments were carried out for finding measures to conduct fungiproofing of pulp and at the same time manufacturing mildew resistant papers. As a result, we could gather valuable data which are accompanied in this literature.

\section{は じめに}

製紙工場にスライムはつきものである。これは時々 洗い落すより他に仕方のないるのだということは極く 最近までいわれていたことである。

近来パルプの歩留りを上け゚るために白水の回収率が 増大されるにつれて, スライムの発生も多くなり, 殺菌 剤によるスライムのコントロールか゚本格的に考えられ， 実行され出したことは一大進歩というべきであろう。

欧米でもスライムコントロールについてはあまり研 究されて扣らず比較的未開の分野であったが，第 2 次 大戦後殺菌剤の飛躍的発達にともない急速にすぐれた スライムコントロール剤が出現し, 現在ではスライム コントロールを行うことが常識となってきたようであ る。

筆者等は国内各地の製紙工場のスライムや白水を集 めて, それから種々の微生物を分離し,この菌を使用 して数種の殺菌剤の発育阻止効果を調べたのでここに 報告する。

\section{スライムと微生物}

スライムが微生物に基因することは早くから知られ ており, 英国の D. K. Pattillo. 米国の C. M. Baker 等の報告もあり Corrigan は硫酸銅, 硝酸カリ, 硫酸 亜鉛，ホウ酸，石炭酸等 の使用を既に 1920 年に 推奖 している。

筆者等は製紙工場のビータ, チェスト，リフラー， ワイヤー下等の白水やリフラー, ワイヤー下等に付着 しているスライムを採集し, 或いは GP，KP，ワラパ ルプ等に色素や徽の発生したものを集めて細菌学的な 分離を試みた。

\footnotetext{
*原稿受付 34.1 .13

*米パーマケム・アジア(株)

*关米浜野織維工業 $\mathrm{KK}$
}

その結果，スライム発生の多い工場ほど白水中にも 多数の微生物が分離され，スライムからも同様である ことがわかり，スライムは微生物に基因して起ること が裏付されたのである。

一方各製紙工場の用水中の微生物を調べたところ, 検出された菌はいずれも Escherichiacoli かそれと同 系の菌で, 酵母, 糸状菌 (徽) はほとんど発見出来な かった。

これはスライムの原因となる菌の大部分は用水から ではなく, 大気中の微生物, あるいは原料やその他の 添加物から混入されるものと推定される。

これ等の微生物を原料別に見ると SP，和紙には細 菌が多く, 次いで酵母が多く, 糸状菌 (微) は比較的

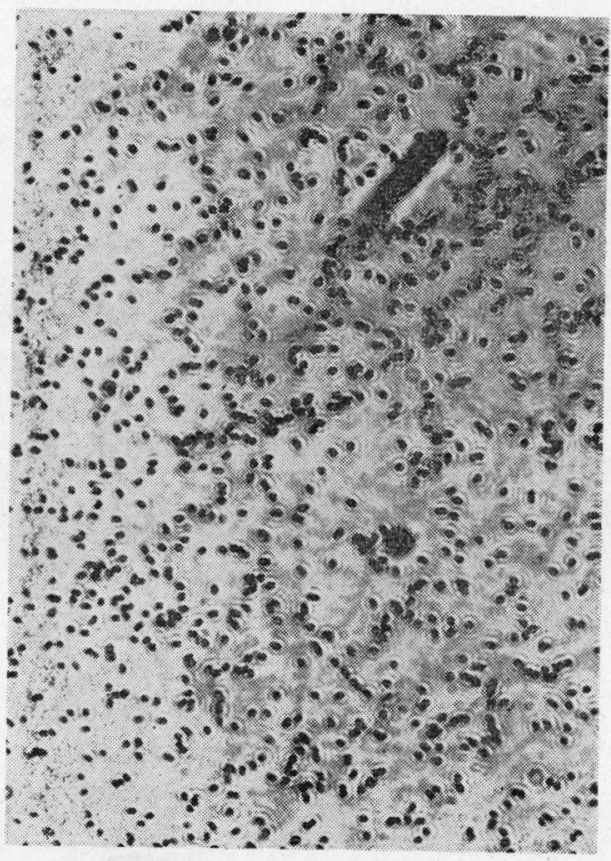

写真 1. Bacillus subtilis $\mathrm{X} 1,500$ 
少ない。KP，ワラパルプ，竹パルプ等は細菌及び糸 状菌（徽）が多く，GP，故紙等は糸状菌が多く酵母， 細菌は少なくなかった。

パルプに発生した菌は総てスライムに出て来るるの と同一のもので糹状菌である。

\section{微生物の種 類}

白水及びスライムから分離された菌種は，比較的多 いので以下属別に列記する。

Bacillus

Pseudomonas

Micrococcus

Escherichia

Aerobacter

以上が細菌の主なものであるが，細菌の中でも $\mathrm{Ba}$ cillus が最も多く, Bacillus subtilis, B. megatherium, B. mycoides 等がその主体を成している。

酵母系としては，よく見られたものは不全菌区に属 するものであり，系状菌（徽）は日常どこにでもよく ある種類のものが多かった。次にその名称を列記する。

Monilia

Fusarium

Rhodotorula

Trichoderma

Mucor

Rhizopus

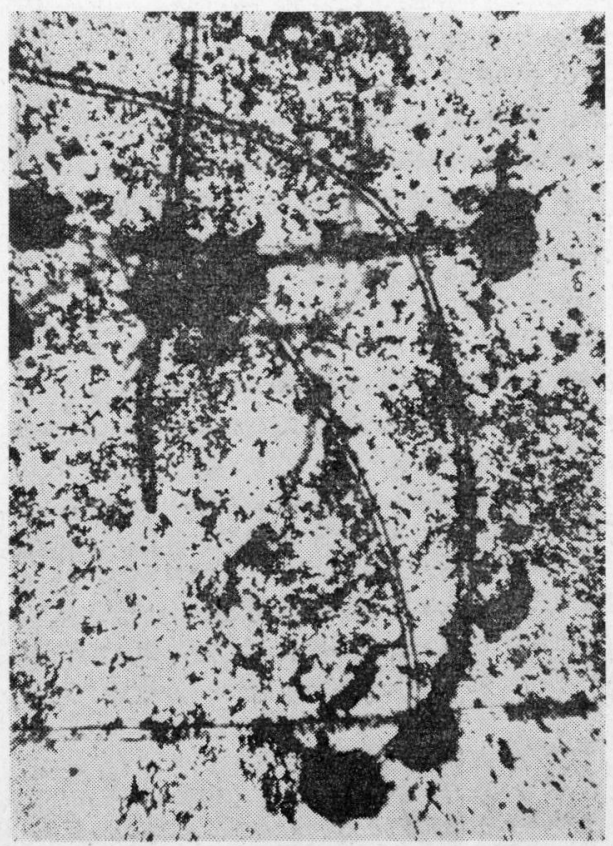

写真 2.Aspergillus niger X 150
Cladosporium

Penicillium

Aspergillus

以上がその主なるのであるが，この他にも Torulopsis, Chaetomium, Trichothecium, Gliocladium等が 時々認められ，又 Aspergillus などは種類も多くAsp. fumigatus, Asp. glaucus, Asp. oryzae, Asp. niger, Asp. versicolor. Asp. terreus, Asp. tamarii 等であ り, Penicillium でも比較的珍しいといわれる Penicillium lilacinum が認められた。

これ等の微生物の幾種類かが互いに共存し，からみ 合ってスライムが形成されて行くと考えられ，1つの 工場の 1 台の機械の白水又はスライムから少くて数種 類，多い場合には 20 種近い微生物が検出されたので ある。

表 ; 1 白水から分離した微生物（工場別）

\begin{tabular}{|c|c|c|c|c|}
\hline 工場名 & 試 料 & 菌 & 醏 & 系 状 菌 \\
\hline $\begin{array}{l}\mathrm{D} \text { 製紙 } \\
\mathrm{S} \text { 工場 }\end{array}$ & $\begin{array}{l}\text { ワイヤー } \\
\text { 下白水 }\end{array}$ & $\begin{array}{l}\text { Bacillus } \\
\text { Micrococcus }\end{array}$ & & $\begin{array}{l}\text { Penicillium } \\
\text { Aspergillus } \\
\text { Rhizopus }\end{array}$ \\
\hline $\begin{array}{l}\text { H製紙 } \\
\text { F工場 }\end{array}$ & $\begin{array}{l}\text { リフラー } \\
\text { 内白水 }\end{array}$ & $\begin{array}{l}\text { Bacillus } \\
\text { Pseudomonas }\end{array}$ & & $\begin{array}{l}\text { Aspergillus } \\
\text { Chaetomium } \\
\text { Penicillium } \\
\text { Cladosporium }\end{array}$ \\
\hline $\begin{array}{l}\text { J製紙 } \\
\text { Y工場 }\end{array}$ & $\begin{array}{l}\text { ワイヤー } \\
\text { 下白 水 }\end{array}$ & $\begin{array}{l}\text { Bacillus } \\
\text { Micrococcus } \\
\text { Peseudomonas } \\
\text { Escherichia }\end{array}$ & Monilia & $\begin{array}{l}\text { Penicillium } \\
\text { Rhizopus } \\
\text { Mucor } \\
\text { Aspergillus }\end{array}$ \\
\hline $\begin{aligned} \text { O製紙 } \\
\text { 幺工場 }\end{aligned}$ & $\begin{array}{l}\text { ワイヤー } \\
\text { 下白水 }\end{array}$ & Bacillus & $\begin{array}{l}\text { Rhodoto- } \\
\text { rula }\end{array}$ & $\begin{array}{l}\text { Aspergillus } \\
\text { Penicillium } \\
\text { Rhizopus }\end{array}$ \\
\hline
\end{tabular}

[附記]

\section{白水又はスライム中の微生物の分離及び 発育抑制効果試験法}

1）白水又はスライムより微生物の分離

使用する試験管, フラスコ等は綿栓を施しシャーレ, ピペット等の器具は紙に包み約 $170^{\circ} \mathrm{C}$ にて 2 時間乾熱 隇菌しておく。

蒸溜水，培養基等は乾熱隇菌を行った試験管，フラ スコ等に入れオートクレーブを用いる場合は $120^{\circ} \mathrm{C} に$ て 20 分間蒸気隇菌を行 5。コッホ滅菌器を用いる場 合は $100^{\circ} \mathrm{C}$ の蒸気中に 30 分間減菌を行い，これを 24 時間間隔にて 3 日間繰返す。このようにして隇菌した 蒸溜水で白水又はスライムを適宜稀釈分散させ寒天を 含む培養器に混じてシャーレに注ぎ細菌の場合は $37^{\circ} \mathrm{C}$ にて $24 \sim 48$ 時間，酵母及び菌（カビ）の場合は $28^{\circ} \mathrm{C}$ にて 48 時間〜 7 日間培養を行う。

なお培養基は菌の種類によって異ったものを使用す 
る。菌の種類によって別々のコロニーを形成するから 白金線を用いて菌を取り，新しい寒天培地飞接種し再 び培養する。

2）試験に使用する培養基

\begin{tabular}{|c|c|c|}
\hline \multirow[t]{3}{*}{ a) } & 肉 & $55.0 \mathrm{~g}$ \\
\hline & ペプトン & $10.0 \mathrm{~g}$ \\
\hline & 塩 & $5.0 \mathrm{~g}$ \\
\hline & 蒸 溜 水 & 11 \\
\hline b) & ペプトン & $10.0 \mathrm{~g}$ \\
\hline & ブドー糖 & $40.0 \mathrm{~g}$ \\
\hline & 蒸 溜 水 & 11 \\
\hline & しょ糖 & $30.0 \mathrm{~g}$ \\
\hline & $\mathrm{NaNO}_{3}$ & $2.0 \mathrm{~g}$ \\
\hline & $\mathrm{K}_{2} \mathrm{HPO}_{4}$ & $1.0 \mathrm{~g}$ \\
\hline & $\mathrm{KCl}$ & $0.5 \mathrm{~g}$ \\
\hline & $\mathrm{MgSO}_{4} \cdot 7 \mathrm{H}_{2} \mathrm{O}$ & $0.5 \mathrm{~g}$ \\
\hline & $\mathrm{FeSO}_{4}$ & $0.01 \mathrm{~g}$ \\
\hline & 蒸 溜 水 & 11 \\
\hline
\end{tabular}

寒天培养基とするには a)，b)，c）の各培盖基飞 1.5 2.5\%の寒天を添加溶解して用いる。a）は主と して細菌，b）及び c) は酵母及び菌汇直応した培地 を使用することもある。

\section{3） Permachem SL-55 の発育抑制効力試験}

細菌：分離の完了した菌の 1 白金耳量（白金線の 先を丸くしたもので 1 カキした量）をa の寒天を加党

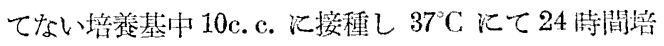
盖する。こうすることによって細菌が発有し液は白濁 する。この 1 白金耳量を寒天を加党てない、a）の培盖 基飞 Permachem SL-55 を 1ppm, 10ppm, 100ppm, ……の割で加えたるの及び Permachem SL-55 を全 く含まないものの 10 c. c. 中に接種し $37^{\circ} \mathrm{C}$ にて24 48 時間培盖を行う。細菌が発育したものは白濁し, 発育の 少ないものは濁りも少なく全く発育していないるのは 透明であるから比濁計を用いて発育の有無を判定する。

酵将：b）の寒天を加党てない培地を用いて細菌 と同様の方法で $28^{\circ} \mathrm{C}$ 亿て培養を行うか又は b) 或い は c) の寒天培地を用いて菌と同じ方法で試験を行う。

菌（カビ）： b) 又はc) 汇寒天を加えた培地汇 Permachem SL-55を 1ppm, 10ppm, 100ppm,…‥の割 で加えたもの及び Permachem SL-55 を全く含をな いものの 10c. c. をシャーレに分注し, 分離の完了し た菌の 1 白金耳量（菌の場合は白金線の先をカギ形に 曲げて抢く）を接種し 28 C そて7 日間培着する。発 春が阻止されていないものは十分に菌系が生育し胞子 も形成する。ある程度阻害されたものは菌系のみが生 育し完全仰抑制されたものは全く生育が認められない。

この発育の状態を観察して判定する。

4) 判 定 法

判定は次の 4 段階に分けて行う。

一 全く菌の発育が浔められず完全に発育が阻止され た状態

土菌が発育しているかどうか明確でないが，ほぼ完 全に発育が阻止された状態

＋僅か㴕が発育しているがある程度の発育阻止効 果が認められる状態

++ 菌が完全に発育し全く阻止効果の䘛められない 状態

(1)

\section{製紙工程中での微生物の発育}

細菌, 酵母, 糸状菌などの微生物は地球上ほとんぞ 至る所注息している。これが或いは食物の腐敗を起 し, 或いは人の病原菌となり, 或いは雨季のカビとな るのである。

微生物はそれが好む栄養物や湿度や温度を与兄ると

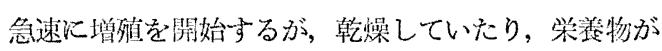
なかったり，温度が低いところでは，活動を止めて静 止の状態入り，その委委生命た沪榀っている。

こうして潜んでいたものが裴紙工程中に混入して来 ると，そこには十分な湿気と温度及びある程度の栄盖 物（主として含承炭素）がめるので直ちに活陲学始め 急速に数が増え，それがスライムとなって山らわれる のである。

ところが, 一日微生物といってもとの栕類によっ て好む条件が買なる。細菌は主として蛋白質を栄養源 とし, 発育汇適した温度は $37^{\circ} \mathrm{C}$ 前後であるが，カビ

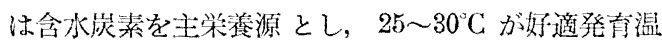
度である。又細菌は PH7 付近が発充偪し酸珄では 発育出来ないが，カビは酸性を好及 PH5〜6が最も発 育邀している。

これ等のことから考劣て製綎工程にはカビが発生し 易いことがわかるが，実際现化述べた如くスライムに はカビが最も大きく影響しているようであり，種類も 多く検出されている。

外国では比較的紐菌が多いようで，スライムコント ロールも細菌を主眼目としているようであるが, 我が 国恃世界でも最もカビの多い国であり，製紙工業も例 外ではなくスライムも䋖菌よりもむしろカビの方が重 要な因子となっているのである。

\section{スライムの防止}

スライムは既汇知られている如く, 紙切れの原因と

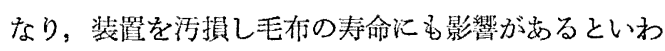


表 : 2 phenol の微生物発育抑制試験成積

\begin{tabular}{|c|c|c|c|c|c|c|c|c|c|c|}
\hline p.p.m. & 1,000 & 500 & 100 & 50 & 10 & 5 & 1 & 0.5 & 0.1 & 0 \\
\hline Bacillus subtilis & \pm & H & $H$ & $H$ & + & $H$ & $\dddot{4}$ & $H$ & $\#$ & t+ \\
\hline Micrococcus pyogenes & \pm & Ht & $H$ & $H$ & $H$ & $H$ & $H$ & H & $H$ & ti \\
\hline \multicolumn{11}{|c|}{ 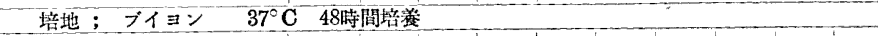 } \\
\hline p.p.m. & 1,000 & 500 & 100 & 50 & 10 & 5 & 1 & 0.5 & 0.1 & 0 \\
\hline Torulopsis candida & \pm & H & $H$ & $H$ & $H$ & tt & $H$ & H & it & $H$ \\
\hline Fusarium culmorum & - & $H$ & 4 & $H$ & $H$ & $H$ & $H$ & $H$ & Ht & $H$ \\
\hline Aspergillus niger & - & $H$ & it & $H$ & $H$ & $H$ & $H$ & $H$ & $H$ & $H$ \\
\hline Penicillium citrinum & - & tt & $H$ & $H$ & tt & $H$ & $H$ & Ht & t+ & H \\
\hline
\end{tabular}

表: 3 Na-Pentachlorophenol の微生物発育抑制試験成繢

\begin{tabular}{|c|c|c|c|c|c|c|c|c|c|c|}
\hline p.p.m. & 1,000 & 500 & 100 & 50 & 10 & 5 & 1 & 0.5 & 0.1 & 0 \\
\hline Bacillus subtilis & - & - & - & \pm & + & H & H & $H$ & H & $\#$ \\
\hline Micrococcus pyogenes & - & $-\cdot$ & - & - & - & + & \# & $H$ & $H$ & H \\
\hline \multicolumn{11}{|c|}{ 培地； プシン $37^{\circ} \mathrm{C}$ 48時間培養 } \\
\hline p.p.m. & 1,000 & 500 & 100 & 50 & 10 & 5 & 1 & 0.5 & 0.1 & 0 \\
\hline Torulopsis candida & - & \pm & + & H & H & H & $H$ & $H$ & H & H \\
\hline Fusarium culmorum & - & - & - & + & $t+$ & H & H & tt & H & $H$ \\
\hline Aspergius niger & - & - & - & + & $H$ & tt & $H$ & $H$ & $H$ & tt \\
\hline Penicillium citrinum & - & - & - & \pm & $H$ & H & H & H & $H$ & $H$ \\
\hline
\end{tabular}

表 : $4 \mathrm{Hgcl}_{2}$ の微生物発育抑制試験成績

\begin{tabular}{|c|c|c|c|c|c|c|c|c|c|c|}
\hline p.p.m. & 1,000 & 500 & 100 & 50 & 10 & 5 & 1 & 0.5 & 0.1 & 0 \\
\hline Bacillus subtilis & - & $\cdots$ & - & - & - & - & - & + & it & H \\
\hline Micrococcus Pyogenes & - & - & - & - & - & - & - & + & H & it \\
\hline 境地；ブイシシ & C 48 時 & 間培方 & & & & & & & & \\
\hline p.p.m. & 1,000 & 560 & 100 & 50 & 10 & 5 & 1 & 0.5 & 0.1 & 0 \\
\hline Torulopsis candida & - & - & \pm & \pm & \pm & + & $H$ & $H$ & it & $H$ \\
\hline Fusarium culmorum & - & - & - & \pm & $H$ & H & H & $H$ & $H$ & $H$ \\
\hline Aspergillus niger & - & \pm & + & + & $\#$ & H & H & Ht & $H$ & it \\
\hline Penicillium citrinum & - & - & \pm & + & it & $\dot{H}$ & H & it & H & tt \\
\hline
\end{tabular}

あるが，これは毒性が強く，余り大量 には使用出来ない。実際に水に溶かし て使用している程度の量では細菌は殺 すことが出来ても，系状菌の発育を抑 制与ることは出来ない。

又有機塩素化合物である Penta chjorophenol はナトリウム塩などの形と して水溶性にすることが出来るが，有 效量が細菌では，50ppm，系状菌では $100 \sim 1,000 \mathrm{ppm}$ となり，殺菌荗として は比較的大量を要し，しかも添加はビ ータからリフラーの間で行うことを要 するので，その酸性のため Penta chlorophenol が固体となって遊離する。 更に特異の刺㦸臭もむり，実用として は余り歓迎されていない。

昔から最名強力な殺菌剤として知ら れている水銀化合物のうち, 苌来は細 菌に対しては極めて少量で糸状菌に詨 しても少い量でとの発育を阻止するが， 有機物（特に蛋白質）に合うととの効 力は急激江低下方合。有機水銀化合物 では，ある程度この点は改良されるよ うであるが，いずれにしてる水銀化合 物は人体に対して猛毒であるので取报 上種々の困難があり，現在侜用されて いるような形のものでは表 6 に当示す 如く細菌に低低清度で有效であるが， 系状菌, 特に Aspergillus 系に対して は相当高濃度であることを要する。
れ，その他作業上汇種々の支障を来すものであるが，

これを防止するにはいくつかの方法が考えられる。

スライムの付着し易い鉄パイプは, 塩ビパイプに交 换するとか, リフラーを滑らかなプラスチック板を張 るとか，特殊な塗料で塗装するということも一つの方 法であろら。

しかし根本原因が徴生物である以上は，その繁殖す るのを阻止しなければ完全な防止は出来得ない。

微生物の発育を阻止する為には，殺菌珴を使用する のが最も良い方法であるが，我々が日常使用している 殺菌㓮る多種多椂である。しかし現在まで研究されて 来た殺菌剂は，そのほとんどが病源菌，痛敗菌を対照 としたもので, 腐敗菌の発育も阻止し, 同時に糸状菌 にも有效に㗢くというものはほとんど無かった。この ことについて, 製紙関係に比較的用いられた殺菌剈を 例に取って，以下に述べて見よう。

最も手近で安価で，しかも有効なものは塩素 $(\mathrm{Cl}) て ゙$
Phenyl mercuric acetate は細菌, 糸状菌共に比較 的少量で有效であるが, 水, 有機溶媒共漂めて溶解 し難く，使用し易い郕形を得ることが困難である。

前にも述べた如く, 細菌に有効な殺菌剂のほとんど すべては，系状菌に刘する発育阻止力が弱く，要らゆ る微生物に効して一様に効果のある殺菌刜にないので ある。

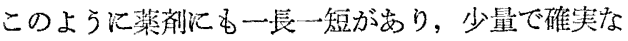
効果を举げるるのがなかなか発見されなかった。

最近朄のパーマケム社から発売されたスライムコ ントロール用薬剤は，有機錫化合物を主成分とし，ス ライムの原因となる微生物のほとんどすべてのものに 極く微量で有効であり, 特に系状菌に対しても, 細菌 そほとんど同じ濃度でとの発育を抑制する。

しかも人体に対する毒性は極めて少なく原液が皮䖉 に付着しても何等障害を起さない。

このことは今までの殺菌凧との大きな相違点であり, 
表:5 Phenyl mercuric acetate の微生物発育抑制試験成績

\begin{tabular}{|c|c|c|c|c|c|c|c|c|c|c|}
\hline p.p.m. & 1,000 & 500 & 100 & 50 & 10 & 5 & 1 & 0.5 & 0.1 & 0 \\
\hline Bacillus subtilis & - & - & - & - & - & - & - & + & $H$ & $H$ \\
\hline Micrococcus Pyogenes & - & - & - & - & - & - & - & + & $H$ & $H$ \\
\hline \multicolumn{11}{|c|}{$37^{\circ} \mathrm{C} 48$ 時間培裳 } \\
\hline p.p.m. & 1,000 & 500 & 100 & 50 & 10 & 5 & 1 & 0.5 & 0.1 & 0 \\
\hline Torulopsis candida & - & - & - & - & - & \pm & + & H & H & $H$ \\
\hline Fusarium culmorum & - & - & - & - & - & \pm & + & $H$ & tt & $H$ \\
\hline Aspergillus niger & - & - & - & \pm & + & + & $H$ & $H$ & $H$ & $H$ \\
\hline Penicillium citrinum & - & - & - & - & - & \pm & + & Ht & $H$ & $H$ \\
\hline
\end{tabular}

表 : 6 スライムコントロール剂 $\mathrm{A}$ の微生物発育抑制試験成續

\begin{tabular}{|c|c|c|c|c|c|c|c|c|c|c|}
\hline p.p.m. & 1,000 & 500 & 100 & 50 & 10 & 5 & 1 & 0.5 & 0.1 & 0 \\
\hline Bacillus subtilis & - & - & - & - & - & - & \pm & + & $H$ & H \\
\hline Micrococcus Pyogenes & - & - & - & - & - & - & \pm & + & $H$ & $H$ \\
\hline \multicolumn{11}{|c|}{ 培地；フフイシン $\quad 37^{\circ} \mathrm{C}$ 48時間培䅅 } \\
\hline p.p.m. & 1,000 & 500 & 100 & 50 & 10 & 5 & 1 & 0.5 & 0.1 & 0 \\
\hline Torulopsis candida & - & - & - & - & + & $H$ & $\#$ & H & $H$ & $H$ \\
\hline Fusarium culmorum & - & - & - & + & $H$ & $H$ & $H$ & $H$ & $H$ & H \\
\hline Aspergillus niger & - & \pm & + & $H$ & $H$ & $\mathrm{H}$ & $H$ & $H$ & $H$ & $H$ \\
\hline Penicillium citrinum & - & & - & \pm & $H$ & $H$ & H & $H$ & $H$ & $H$ \\
\hline
\end{tabular}

表 : 7 スライムコントロール剂 Permachem SL-55の微生物発 青抑制試験成績

\begin{tabular}{|c|c|c|c|c|c|c|c|c|c|c|}
\hline p.p.m. & 1,000 & 500 & 100 & 50 & 10 & 5 & 1 & 0.5 & 0.1 & 0 \\
\hline Bacillus subtilis & $\cdots$ & - & - & - & - & - & \pm & + & $H$ & H \\
\hline Micrococcus Pyogenes & - & - & - & - & - & - & + & + & H & tt \\
\hline \multicolumn{11}{|c|}{ 培地：プアン $37^{\circ} \mathrm{C}$ 48时間培棠 } \\
\hline p.p.m. & 1,000 & 500 & 100 & 50 & 10 & 5 & 1 & 0.5 & 0.1 & 0 \\
\hline Torulopsis candida & - & - & - & - & \pm & + & H & H & H & $\mathrm{H}$ \\
\hline Fusarium culmorum & - & - & - & - & + & tt & H & H & H & tf \\
\hline Aspergillus niger & - & - & - & - & + & $H$ & tt & H & H & it \\
\hline Penicillium citrinum & - & - & - & - & \pm & H & H & H & H & it \\
\hline
\end{tabular}

抑制効果のないことがわかる。

以上に述べた菜剤を比較すれば Permachem の特性を知ることが出来 るであろう。

今まではスライムコントロールには 水銀系の薬剂のみが使用されて来たこ とは篦知のことであるが，前にも述べ た如く，この薬剤の特性として細菌に は有效であるが, Aspergillus 等の力 ビに対して効果が少ない為，使用を継 続すると細菌はほとんど消隇し，殺し 切れないカビだけが残って来る。

微生物の世界では幾種類かが共存し ている場合，互い指抗し合い，自己 の分野を守りながら生存しているので あるが，このうちのあるものが減少又 は死隇して, 均衡が破れると, 残った ものはその分野まで勢力を伸して来る ものである。

前述の場合が丁度これに当り，スラ イムにもカビだけが目立って来, 微生 物があたかも薬品に対して抵抗力を獲 得したかの如き状態を是するものと考 觉られ，こういう状沉はよく経験され ることである。

この理由からすれば，水銀系薬郕一。 種によって連続で便用することは，ま ことに危険であり，特に系状菌系に対 して效力の大きい薬剂と交互に娔用す ることが望ましく，更に細菌にも酵母
パーマケムの最も特長とする所である。

パーマケムが輸入されて以来，筆者等も有機錫化合 物について研究を重社，パーマケムを更に改良し，よ り少量で，より広い範用の微生物に対して效力を発揮 されるようになった。

有機錫化合物の抗菌性については, 既に G. J. M. Van Der Kerk,. J. G. A. Luijiten 等が報告してお り，多数の化合物を発表している。

その主なるのについて筆者等もこれを合成し，更 にその徳生物に対する抵抗性を調べたので，ここに Permachem との比較を表示する。（表 8-10参照）

表で明らかな如く, Tri-n-buityltin chloride, bis (Tri-n-butyltinoxide) 等は糸状菌に対しては有效で あるが Escherichia coli, Pseudomonas aeruginosa., Aerobacter aerogenes 等のスライムにしばしば見ら れる細菌類汶対しては， 1,000 p. p. m でもほとんど
にも，糸状菌とも同じ樣に有效であるものが理想的で むる。

Permachem SL-55 は瀻維にほとんど吸着されない ので, スライム・コントロールに使用するにはビータ 又はチェスト内に添加出来る。スライムコントロール 剤はリフラーとかフローボックスで添加するよりビー タ・チェスト壁化付着するスライムを防止出来るの でビータ添加を行う方がより良いことは当然である。

このようにして，スライムを除き，それによる損肯， 例えば紙切れ，損紙を減少させ，掃除の手数を省き， マシンスピードを上昇させることが可能となり，白水 の回収率を增加して絒維の歩留りを多くして大きな利 益をもたらすことが出来るであろう。

\section{パルプの防徽について}

KP, GPその他のパルプが保存中に糸状菌が発生し, 
表 : 8 Tri-n-butyltin chloride の微生物発育抑制試験成績

\begin{tabular}{|c|c|c|c|c|c|c|c|c|c|c|}
\hline p.p.m. & 1,000 & 500 & 100 & 50 & 10 & 5 & 1 & 0.5 & 0.1 & 0 \\
\hline Escherichia coli & + & + & $H$ & $H$ & $H$ & $H$ & H & $H$ & $H$ & $H$ \\
\hline Pseudomonas aeruginosa & + & $H$ & $H$ & Ht & $H$ & $H$ & $H$ & $H$ & $H$ & tt \\
\hline Aerobacter aerogenes & + & $H$ & $H$ & $H$ & $t+$ & $H$ & H & $H$ & $H$ & H \\
\hline \multicolumn{11}{|c|}{ 培地；ブイシン $\quad 37^{\circ} \mathbf{C}$ 24時間培養 } \\
\hline p.p.m. & 1,000 & 500 & 100 & 50 & 10 & 5 & 1 & 0.5 & 0.1 & 0 \\
\hline Aspergillus niger & - & - & - & \pm & + & $H$ & $H$ & it & $H$ & $H$ \\
\hline Penicillium citrimum & - & - & - & - & + & + & $H$ & $H$ & $H$ & $H$ \\
\hline
\end{tabular}

表 : 9 bis（Tri-n-butyltinoxide）の微生物発育抑制試験成績

\begin{tabular}{|c|c|c|c|c|c|c|c|c|c|c|}
\hline p.p.m. & 1,000 & 500 & 100 & 50 & 10 & 5 & 1 & 0.5 & 0.1 & 0 \\
\hline Escherichia coli & + & + & H & $H$ & $H$ & $H$ & $H$ & $H$ & H & $H$ \\
\hline Pseudomonas aeruginosa & + & + & $+t$ & $H$ & $\because+$ & $H$ & $H$ & $H$ & $H$ & $H$ \\
\hline Aerobacter aerogenes & + & + & $H$ & H & $H$ & H & $H$ & it & $H$ & t+ \\
\hline \multicolumn{11}{|c|}{ 培地； プイシン $37^{\circ} \mathrm{C}-24$ 時間培意 } \\
\hline p.p.m. & 1,000 & 500 & 100 & 50 & 10 & 5 & 1 & 0.5 & 0.1 & 0 \\
\hline Aspergillus niger & - & - & - & \pm & + & H & $H$ & $H$ & $H$ & $H$ \\
\hline Penicillium citrinum & - & - & - & - & \pm & + & $H$ & $H$ & $H$ & $H$ \\
\hline
\end{tabular}

表 : 10 Permachem SL-55 の微生物発育抑制試験成績

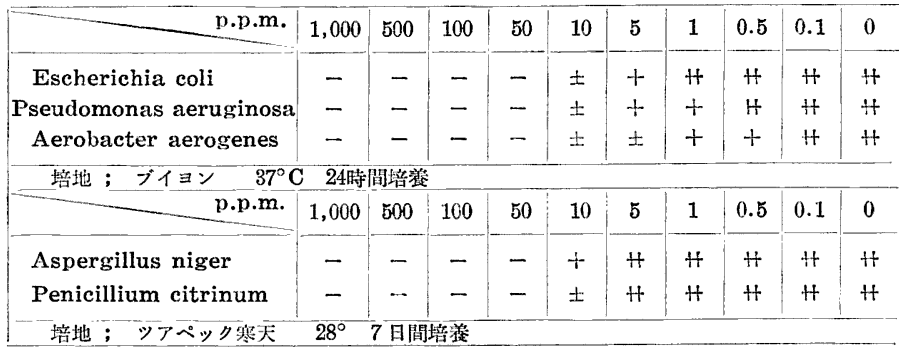

た。

試料として L. B. KP を使用し， これに市販のスライムコントロール凮 A 及びパーマケム SL-55 の水溶液を スプレーにより吸収させ，絶乾パルプ 当り $10 \sim 100$ p.p.m 付着するように調 整した。

この試料を $2.5 \mathrm{~cm}$ 角に切り，オート クレーブにて減菌を行い，予め無菌的 に調整した，ッアペック寒天平板上に 密着させる。-方,パルプより分離した 系状菌Trichoderma, Penicillium及び Aspergillus を用い，それぞれについ て胞子奬濁液を作り，これを試料 1 当 り $0.5 \mathrm{cc}$ ずつ均等に按種して $28^{\circ} \mathrm{C}$ に て，7日間培善を行った。その結果を 表 : 11亿示す。

この表で明らかな如く, Permachem は良好な防微効果を発揮している。

Permachem SL-55は繊維に吸着さ れず，付着しているのみであるから， 水で洗うことによって簡単に洗い去る ことが出来る。

\section{防徽紙の製造}

食品用防腐䋊の製造に O-Phenyl phenol を使用することが Tomkins に その為污染されることは前に述べたが，この系状菌 （カビ）を防ぐことは比較的簡単に行い得る。

これを確認するため，筆者等は次の如き実験を行っ

表 : 11

供試菌：Trichoderma

\begin{tabular}{|c|c|c|c|c|c|}
\hline 薬 品 p.p.m. & 100 & 50 & 20 & 10 & 0 \\
\hline $\begin{array}{l}\text { 市 肘 品 } A \\
\text { Permachem } \\
\text { SL-55 }\end{array}$ & sl. + & $\begin{array}{l}+\mathrm{m} 50 \% \\
\text { sl. }+\end{array}$ & $\begin{array}{l}+\mathrm{m} 100 \\
\text { sl. }+\end{array}$ & $\begin{array}{l}+1 \\
+n\end{array}$ & $H \mathrm{~s}$ \\
\hline \multicolumn{6}{|c|}{ 供試菌： Aspergillus } \\
\hline 薬 㩊 $\quad$ p.p.m. & 100 & 50 & 20 & 10 & 0 \\
\hline $\begin{array}{l}\text { 市 肘 品 A } \\
\text { Permachem SL-55 }\end{array}$ & $\begin{array}{l}\text { its } \\
\text { sl. }\end{array}$ & $\begin{array}{l}\text { H s } 100 \\
\text { sl. }+\end{array}$ & & & 00 \\
\hline \multicolumn{6}{|c|}{ 供試菌：Penicillium } \\
\hline 薬 嵒 p.p.m. & 100 & 50 & 20 & 10 & 0 \\
\hline $\begin{array}{l}\text { 市 股 品 } \begin{array}{c}\text { A } \\
\text { Permachem }\end{array} \text { SL-55 }\end{array}$ & $\begin{array}{c}\% \\
+\mathrm{m} 100 \\
-\end{array}$ & $\begin{array}{l}+\mathrm{m} 100 \\
\text { sl. }+\end{array}$ & $\begin{array}{l}+\mathrm{s} 20 \\
+\mathrm{m} 20\end{array}$ & $\begin{array}{l}+\mathrm{s} 100 \\
+\mathrm{m} 30 \%\end{array}$ & 00 \\
\hline
\end{tabular}

注 一 と虹試料面に全く菌の発育しないるの。

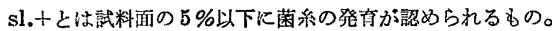

+ 々は融料面の $5 \%$ 以上菌系の発育が認められるものをいい, m.一\%は試料面汇発生した菌系の昷を表別す。

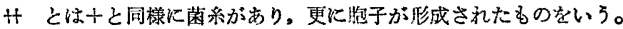
s.一\%は訊料面に発生した胞子の量を表放す。
よって発見され，更に果物の防腐用に第四級アンモニ ウム化合物が有效であると報告されている。

その他 Chlorinated phenol, Diphenyl, 有機水銀化 合物，有機銅化合物，有機金属塩による種々の実験が 過去に竌いて行われた。

しかしこれらのもののあるものは，紙に対する定着 能が低かったり，徽生物の種類によって効果にむらが あったりして，種々の目的のために同一に使用するこ とが出来ない。

Permachem SL-55 は紙にスプレーすることにより， 又は RF サイズーXとの併用によってビータ 添加によ り完全に紙に定着する。

この絟を土壤中に埋没しても，土壌中の微生物に侵 され，強度の減退することが極度に抑制出来，䋊の寿 命が延長される。

又この紙で食品を包めばカビの発生を完全に抑制し， 腐敗を防ぐので貯蔵に好適である。

最近食品そのものには，防腐剤が添加されることが (266 頁へ続く) 
第 5 表 対のあるデータとしての有意差検定

\begin{tabular}{|c|c|c|c|c|c|c|c|c|}
\hline \multirow{2}{*}{ 試験回数 } & \multicolumn{4}{|c|}{ 対のあるデータとして $A-C=x$} & \multicolumn{4}{|c|}{$B-C=y$} \\
\hline & $A$ & $C$ & $x$ & $x^{2}$ & $B$ & $C$ & $y$ & $y^{2}$ \\
\hline 1 & 13 & 4 & 9 & 81 & 9 & 4 & 5 & 25 \\
\hline 2 & 7 & 5 & 2 & 4 & 4 & 5 & -1 & 1 \\
\hline 3 & 10 & 2 & 8 & 64 & 18 & 2 & 16 & 256 \\
\hline 4 & 11 & 9 & 2 & 4 & 7 & 9 & -2 & 4 \\
\hline 5 & 16 & 4 & 12 & 144 & 9 & 4 & 5 & 25 \\
\hline 6 & 6 & 3 & 3 & 9 & 17 & 3 & 14 & 196 \\
\hline 7 & 7 & 3 & 4 & 16 & 18 & 3 & 15 & 225 \\
\hline 8 & 10 & 9 & 1 & 1 & 15 & 9 & 6 & 36 \\
\hline 9 & 10 & 3 & 7 & 49 & 3 & 3 & 0 & 0 \\
\hline 10 & 18 & 5 & 13 & 169 & 12 & 5 & 7 & 49 \\
\hline 11 & 13 & 4 & 9 & 81 & 8 & 4 & 4 & 16 \\
\hline 12 & 15 & 1 & 14 & 196 & 16 & 1 & 15 & 225 \\
\hline 13 & 13 & 7 & 6 & 36 & 19 & 7 & 12 & 144 \\
\hline 14 & 17 & 6 & 11 & 121 & 18 & 6 & 12 & 144 \\
\hline 15 & 17 & 2 & 15 & 225 & 18 & 2 & 16 & 256 \\
\hline 16 & 2 & 9 & $\cdots 7$ & 49 & 17 & 9 & 8 & 64 \\
\hline 17 & 11 & 1 & 10 & 100 & 18 & 1 & 17 & 289 \\
\hline 18 & 11 & 2 & 9 & 81 & 10 & 2 & 8 & 64 \\
\hline 19 & 17 & 6 & 11 & 121 & 1 & 6 & -5 & 25 \\
\hline 20 & 21 & 3 & 18 & 324 & 29 & 3 & 26 & 676 \\
\hline $\begin{array}{l}\text { 計 } \\
\text { 平均 }\end{array}$ & & & $\begin{array}{l}157 \\
7.85\end{array}$ & 1875 & & & $\begin{array}{c}178 \\
8.90\end{array}$ & 2720 \\
\hline
\end{tabular}

a) $(\mathrm{A}) \subset(\mathrm{C})$

平方和 $1875-(157)^{2} / 20=642.5$

標準偏差 $\sigma e=\sqrt{6} 642.5 / 19=5.815$

$$
t x=\frac{7.85}{5.815} \times v 20=6.037
$$

$t(0.001)=3.88$

趴占 $t x \gg t(0.001)$

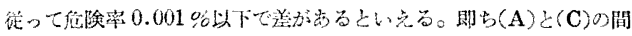

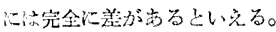

の優秀性が確認された。

往来クレープクラフト紙は通常クラフト紙に 此べ割高になると思われていたが，二層と三層 とでは相当の価格低下が見込まれるので，包装 の面からの大きな合理化を期待することが出来 よう。このことはセメントだけでなく他の重包 装紙袋の向上に資する所大きなものがあると思 われる。

又第 6 表から明らかなようにメラミン樹脂で 加丁すると絓の強度は乾燥時も非常に向上する。 即らメラミン樹脂で加工すると薄くてしかも強 い紙の抄遗が可能であることがわかる。

このことは同時に木材資源の合理化が国家的, 社会的な問題になっている時，木材資源の節約 という意味からも大いに有意義なことと思われ る。

b) (B) $<($ C $)$

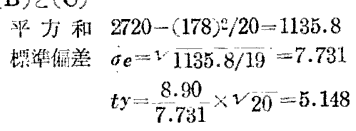

即占 $t y \gg t(0.001)$

\begin{tabular}{|c|c|c|c|c|c|c|c|c|c|c|c|c|}
\hline \multirow{2}{*}{ 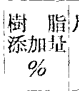 } & \multirow{2}{*}{$\begin{array}{c}\text { 尺 调 } \\
\text { 多 }\end{array}$} & \multirow{2}{*}{$\begin{array}{c}\text { 米坪 } \\
\mathrm{g}\end{array}$} & \multirow{2}{*}{$\begin{array}{l}\text { 厚 } \\
\mathrm{mm} /\end{array}$} & \multirow{2}{*}{$\begin{array}{l}\text { 破裂度 } \\
\mathrm{kg} / \mathrm{cm}^{\mathrm{s}}\end{array}$} & \multicolumn{2}{|c|}{ 抗張力 $\mathrm{kg}$} & \multicolumn{2}{|c|}{ 伸 歪 \% } & \multicolumn{2}{|c|}{ 引裂 度 $\mathrm{g}$} & \multicolumn{2}{|c|}{ 酸斩度 回 } \\
\hline & & & & & 縰 & 横 & 䋐 & 顗 & 䋊 & 樤 & 数 & 檟 \\
\hline 0 & 1.77 & 72.3 & 23.8 & 1 & 3.0 & 2.5 & 12. & 7.8 & 130 & 137 & 以 & $\begin{array}{c}\text { 以 } \\
1000\end{array}$ \\
\hline 3.0 & 1.80 & 73.5 & 24.0 & 3.35 & 5.30 & 4.10 & 12.4 & 6.35 & 125 & 136 & & " \\
\hline
\end{tabular}

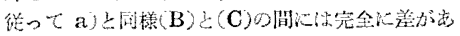
るといえる。

第 6 表 クレープクラフト紙に及ぼすメラミン樹脂加工の影㸷

多くなり，腐欺対しては添济完全に防止しているが，

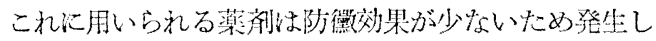
て来石紎菌を抑制与る必要が女り，その目的のため に防徽性の岁る包装絓が釹求されるようになって来た が，その细の分野でも将来防微䋗の要求は増大して来 るものと思われる。

\section{総括}

製絓工場の白水及びスライムから微生物を単離し， その菌種を汰定し本邦のスライムは欧米に比し系状菌 が多いと考察された。またパルプに発生した紎菌に ついる単離を行った。

更にこれらの微生物について，その抑制効果を種々 の薬剤について検討を行った。
本支に述ベた如く，スライムコントロール，パルプ の防微及び防徽紙の製造も有效で要ると思われる藻剂 の使用法について験を行いその結果を報告した。

$$
\text { 文献 }
$$

1) Tappi Vol. 37 (1954)

2) Tappi Vol. 39 (1956)

3) Svensk Papperstidn Vol. 59 (1956)

4) Svensk Papperstidn Vol. 59 (1956)

5) J. Appl. Chem. (1954)

6) J. Appl. Chem. (1956)

7) 微生物学ハンドブック編集委員会編 微生物学ハンドブック

8) 伝染病研究所学友会編 細菌学実習提要

9) 宮路慧二著 応用菌学上卷

10）太田啺人著 合成殺虫, 殺菌, 除草剂

11) 山本亮監修 新農薬研究法 